\title{
ASYNCHRONOUS FORMATION OF ADJACENT EPITHERMAL AU-CU AND PORPHYRY CU-MO DEPOSITS IN THE ZIJINSHAN OREFIELD, SOUTHEAST CHINA
}

\author{
WENTING HUANG ${ }^{1}$, HUAYING LIANG ${ }^{2}$ \\ ${ }^{1}$ wentinghuang@gig.ac.cn \\ ${ }^{2}$ lianghy@gig.ac.cn
}

Adjacent high-sulfidation epithermal (HSE) and porphyry deposits often have similar $\mathrm{Cu}-\mathrm{Au}$ metal associations, suggesting they are cogenetic and formed contemporaneously. The Zijinshan orefield (ZOF) is the largest Au producer in China and contains the largest $\mathrm{HSE} \mathrm{Au}-\mathrm{Cu}$ deposit and porphyry $\mathrm{Cu}-\mathrm{Mo}$ deposit of southeast China. This pair of HSE $\mathrm{Au}-\mathrm{Cu}$ and porphyry $\mathrm{Cu}-\mathrm{Mo}$ deposits is different from the majority of adjacent and cogenetic HSE and porphyry deposits that have similar $\mathrm{Au}-\mathrm{Cu}$ associations.

We present new (1) muscovite ${ }^{40} \mathrm{Ar}-{ }^{39} \mathrm{Ar}$ ages for the HSE deposits in this area, (2) new zircon laser ablationinductively coupled plasma-mass spectrometry (LA-ICP-MS) $\mathrm{U}-\mathrm{Pb}$ ages for felsic igneous rocks associated with the epithermal and porphyry mineralization, and (3) new zircon $\mathrm{Lu}-\mathrm{Hf}$ isotopic data for these intrusions, all of which provide insights into the relationship between this pair of deposits, and why these adjacent epithermal $\mathrm{Au}-\mathrm{Cu}$ and porphyry $\mathrm{Cu}-$ Mo deposits have different metal associations.

The age data indicate that the alunite-dickite alteration related to the $\mathrm{HSE} \mathrm{Au}-\mathrm{Cu}$ mineralization formed before ca. $110 \mathrm{Ma}$ and the main $\mathrm{HSE} \mathrm{Au}-\mathrm{Cu}$ mineralizing event occurred at ca. $113 \mathrm{Ma}$. In comparison, the adjacent porphyry $\mathrm{Cu}-\mathrm{Mo}$ mineralization formed at ca. $104 \mathrm{Ma}$, ca. $9 \mathrm{Myr}$ after the HSE event. The volcanic rocks associated with the HSE $\mathrm{Au}-\mathrm{Cu}$ mineralization yield zircon $\varepsilon \mathrm{Hf}(\mathrm{t})$ values from -4.1 to 0.3 , whereas the $\mathrm{Cu}-\mathrm{Mo}$ mineralized porphyritic intrusion has lower zircon $\varepsilon_{\mathrm{Hf}}(\mathrm{t})$ values $(-4.5$ to -1.2$)$, suggesting that the magmas that formed the latter intrusion were derived from a source containing more crustal material than the magmas associated with the HSE mineralization. The differences in the timing of mineralization and the sources of the magmas indicate that the adjacent HSE and porphyry deposits in the ZOF formed from different magmatic-hydrothermal systems that controlled the different metal associations of the mineralizing systems. This means that future mineral exploration within the $\mathrm{ZOF}$ should target porphyry $\mathrm{Au}-\mathrm{Cu}$ deposits at depths that are genetically related to the HSE Au$\mathrm{Cu}$ deposits. The results also show that not all adjacent porphyry and epithermal deposits, especially those with different metal associations, are cogenetic. 